Article

\title{
In Nitrate-Rich Soil, Fallopia x bohemica Modifies Functioning of N Cycle Compared to Native Monocultures
}

\author{
Amélie A. M. Cantarel ${ }^{1, *, \dagger}$, Soraya Rouifed ${ }^{2, *, t, \ddagger}$, Laurent Simon ${ }^{2}$, Julien Bourg ${ }^{2}$, \\ Jonathan Gervaix ${ }^{1}\left(\right.$, Leslie Blazère ${ }^{1,2}$, Sophie Poussineau ${ }^{2}$, Charline Creuzé des Châtelliers ${ }^{1}$ \\ and Florence Piola $2, *$ D \\ 1 Univ Lyon, Université Claude Bernard Lyon 1, CNRS, INRAE, UMR5557 LEM, F-69622 Villeurbanne, France; \\ jonathan.gervaix@univ-lyon1.fr (J.G.); leslie.blazere@gmail.com (L.B.); \\ charline.creuze-des-chatelliers@univ-lyon1.fr (C.C.d.C.) \\ 2 Univ Lyon, Université Claude Bernard Lyon 1, CNRS, ENTPE, UMR5023 LEHNA, F-69622 Villeurbanne, \\ France; laurent.simon@univ-lyon1.fr (L.S.); bourg.julien69@laposte.net (J.B.); \\ sophie.poussineau@univ-lyon1.fr (S.P.) \\ * Correspondence: amelie.cantarel@univ-lyon1.fr (A.A.M.C.); srouifed@isara.fr (S.R.); \\ florence.piola@univ-lyon1.fr (F.P.); Tel.: +33-472-431-380 (A.A.M.C.); +33-427-858-583 (S.R.); \\ +33-472-432-955 (F.P.) \\ + Equally contributing authors. \\ $\ddagger$ Current address: Isara, AGE-AGroecology and Environment Research Unit, 23 rue Jean Baldassini, \\ 69364 Lyon, CEDEX 07, France.
}

Received: 31 January 2020; Accepted: 15 April 2020; Published: 17 April 2020

\begin{abstract}
The effects of invasive species at the ecosystem level remain an important component required to assess their impacts. Here, we conducted an experimental study with labeled nitrogen in two types of soil (low and high nitrate conditions), investigating the effects of (1) the presence of Fallopia x bohemica on the traits of three native species (Humulus lupulus, Sambucus ebulus, and Urtica dioica) and (2) interspecific competition (monoculture of the invasive species, monoculture of the native species, and a mixture of invasive/native species) on nitrification, denitrification, and related microbial communities (i.e., functional gene abundances). We found that the species with the higher nitrate assimilation rate (U. dioica) was affected differently by the invasive species, with no effect or even an increase in aboveground biomass and number of leaves. F. x bohemica also decreased denitrification, but only in the soil with high nitrate concentrations. The impacts of the invasive species on nitrification and soil microorganisms depended on the native species and the soil type, suggesting that competition for nitrogen between plants and between plants and microorganisms is highly dependent on species traits and environmental conditions. This research highlights that studies looking at the impacts of invasive species on ecosystems should consider the plant-soil-microorganism complex as a whole.
\end{abstract}

Keywords: nitrogen $(\mathrm{N})$ cycle; labeled-N; isotopes; plant-soil competition for soil N; invasive and native species; nitrification; denitrification; abundances of functional genes

\section{Introduction}

Because an invasive species is a new element in a system, it has an impact (positive or negative) on this system simply by being present [1]. Beyond this observation, there is no consistency in research on the ecological impacts of invasive species at the ecosystem level [1], although several reviews and meta-analyses have tried to clarify patterns. Plant invasions can alter various components of 
ecosystems, such as carbon and nitrogen $(\mathrm{N})$ cycles [2-4]. The majority of studies suggest increased mineral and nutrient contents in soils [5]. A meta-analysis including studies on 130 species showed that invasive plants enhanced microbial activity and available $\mathrm{N}$ in soil (e.g., ammoniac or ammonium) and that the effects on nitrification (ammonium- $\mathrm{NH}_{4}{ }^{+}$oxidation to nitrate- $\mathrm{NO}_{3}{ }^{-}$) were highly variable [6]. Higher rates of net $\mathrm{N}$ mineralization (conversion of organic $\mathrm{N}$ to inorganic $\mathrm{N}$ ) and nitrification were reported by literature [7], and an inhibition of nitrification was also shown [8,9]. More recently, it has been shown that some of these invasive plants might play a role in denitrification $\left(\mathrm{NO}_{3}{ }^{-}\right.$reduction into gaseous forms $[10,11])$. All of these studies suggest that invasive plants might have positive or negative feedbacks on soil microorganism functioning, facilitating their establishment in invaded ecosystems, and impacting plant-plant competition for N-substrates [12].

In 2014, Castro-Díez et al. [13] also found an increase in N pools and fluxes that were explained by climate and partly by functional differences between invasive and native species. Plant community composition is theoretically one driver affecting how invasive species will impact resident biota [14]. An invasive species that uses the same resources as the native species but uses these resources more efficiently will result in a scenario of competitive exclusion and is likely to directly impact the microbial community $[1,15]$. In contrast, an invasive plant species that uses different soil resources than those used by the native species can coexist with other plant species [15] but may have indirect impacts on the plant community by affecting soil properties and communities in a new way [1]. Finally, because invasive plant species can substantially alter belowground communities and nutrient cycling and availability and because the magnitude and direction of these impacts are difficult to predict due to the inherent complexity of ecosystems, there is a need for more studies integrating multiple trophic levels $[14,16]$.

Japanese knotweeds s.l. are a tall herbaceous invasive species that form a polyploid hybrid complex including F. japonica, F. sachalinensis, and F. $\mathrm{x}$ bohemica [17]. The latter is the hybrid taxon, phenotypically and genetically more diverse than the two others, and it often shows higher invasiveness [18]. These species are listed as some of the "worst" invasive species based on their impacts. In Nentwig et al.'s list of the worst alien species in Europe [19], which was based on a generic impact scoring system (GISS), Fallopia japonica is ranked 37th out of 86 total species and 12th among plant species. Several studies (reviewed in [20]) have shown that Japanese knotweeds s.l. have major impacts on ecosystems, such as alterations of soil chemistry, leading to increases or decreases in the abundance of soil microorganisms (amoebas or bacteria, respectively), and a disturbance to nutrient cycling [10,11]. These effects have been proven to depend on soil characteristics [11,21]. However, to our knowledge, nothing is known about the influence of the presence of native species co-occurring with $F$. x bohemica, with potentially different nitrogen-use strategies, on soil $\mathrm{N}$ functioning (e.g., nitrification and denitrification). However, there is increasing evidence in the literature that plant nitrogen-use strategies influence the soil microbial community involved in the $\mathrm{N}$ cycle and their functioning [22-24]. In two contrasting soils with different nitrate levels, we aimed to identify (1) the impacts of $F$. x bohemica in mixture with native species on soil $\mathrm{N}$ functioning and associated microbial communities and (2) whether these impacts are driven by native/invasive plant interactions and by different $\mathrm{N}$-use strategies for native species compared to Japanese knotweeds.

We hypothesized that F. x bohemica would (1) inhibit denitrification and (2) increase or not affect nitrification to maintain nitrate available in the soil for its growth, especially in low resource environments (following the niche construction hypothesis), and where the competitive effect of $F . x$ bohemica on native plant species is the strongest.

\section{Materials and Methods}

\subsection{Study Species, Soils, and Plant Regeneration}

Three native species were chosen. Clonal (with a belowground perennial organ) and herbaceous species commonly occurring in the same habitats as F. x bohemica (F) were selected: Urtica dioica (U), 
Sambucus ebulus (S), and Humulus lupulus (H). Individuals from at least 6 populations of each species, separated by at least $3 \mathrm{~km}$, were collected in the Auvergne-Rhône-Alpes region in France (Table S1) and were cultivated in a common garden for approximately 18 months.

Two $2 \mathrm{~mm}$-sieved standardized sandy loam soils were purchased at LUFA Speyer (Speyer, Germany) and chosen based on their physicochemical and textural similarities. The two soils have contrasting soil nitrate $\left(\mathrm{NO}_{3}{ }^{-}\right)$concentrations containing $20 \pm 1.6 \mu \mathrm{g} \mathrm{NO}{ }^{-} \cdot \mathrm{g}^{-1}$ dry soil and $9 \pm 0.8 \mu \mathrm{g} \mathrm{NO}_{3}^{-} \cdot \mathrm{g}^{-1}$ dry soil (hereafter named $\mathrm{N}^{+}$soil and $\mathrm{N}^{-}$soil, respectively). The soil ammonium concentrations were very low for the two soils $\left(0.09 \pm 0.02\right.$ and $0.04 \pm 0.02 \mu \mathrm{g} \mathrm{NH}_{4}^{+} \cdot \mathrm{g}^{-1}$ dry soil).

More than 100 pieces of rhizome or stolon per species and per soil were planted in $0.5 \mathrm{~L}$ pots (one individual per pot), which were filled with one of the two soils, and cultivated in controlled conditions. Because the species showed different regeneration times (U. dioica $>$ S. ebulus $>$ H. lupulus $>$ F. $\mathrm{x}$ bohemica; measured before the experiment using the same plant material cultivated in common gardens, data not published), an interval of several days was allowed between the planting of the species based on their regeneration times. This interval prevented the priority effect from the faster regenerating species and enabled the study to focus on the competition of resource use.

\subsection{Experimental Design}

Ten weeks after the regeneration time, the height of the regenerated plants was measured. The individuals selected for this experiment were near the height mean of each species, regardless of the population, to reduce intraspecific size variability. For each soil, $1.5 \mathrm{~L}$ pots containing two individuals separated by $5 \mathrm{~cm}$ were constituted. Seven competition treatments were created: U-U, F-U, S-S, F-S, H-H, F-H, and F-F, with 8 pots for each combination type of soil $\times$ competition treatment (i.e., 8 repetitions, $n=112$ ). Plants were grown for 6 weeks at $20^{\circ} \mathrm{C}$ with $16 \mathrm{~h} \mathrm{light} / 8 \mathrm{~h}$ dark. Each pot was watered three times a week. After 6 weeks of plant growth, a ${ }^{15} \mathrm{~N}$ labeled $\mathrm{N}$ solution was added to five replicates of each treatment to follow the fate of nitrate in soil and plants, while the other three replicates received unlabeled $\mathrm{N}$ solution to measure the natural isotopic composition in the soil and plants $\left({ }^{15} \mathrm{~N}\right.$ at $\%$ contr $)$.

\section{3. $N$ Addition and Labeling}

To avoid any fertilizing effect in our experiment, the amount of added ${ }^{15} \mathrm{NO}_{3}{ }^{-}$was equal to $5 \%$ of the extractible $\mathrm{NO}_{3}{ }^{-}$that was naturally present in the two soils at the start of the experiment (see Section 2.1). Each pot was watered with $40 \mathrm{~mL}$ of potassium nitrate $\left(\mathrm{KNO}_{3}{ }^{-}\right)$with concentrations of $150 \mathrm{mg} \cdot \mathrm{L}^{-1}$ for $\mathrm{N}$ - soil and $340 \mathrm{mg} \cdot \mathrm{L}^{-1}$ for $\mathrm{N}^{+}$soil. Labeled $\mathrm{K}^{15} \mathrm{NO}_{3}{ }^{-}\left({ }^{15} \mathrm{~N}, 99 \%\right.$, Eurisotop, Saint-Aubin, France) was used for 5 pots per treatment and per soil (3.1 and $6.8 \mathrm{mg} \mathrm{K}^{15} \mathrm{NO}_{3}{ }^{-}$, respectively, for $\mathrm{NO}_{3}{ }^{-}$low and $\mathrm{NO}_{3}{ }^{-}$rich soil per pot), and unlabeled $\mathrm{KNO}_{3}{ }^{-}$was used for 3 pots per treatment and per soil (to measure the natural isotopic composition in the soil and plants).

\subsection{Soil and Plant Harvest and Processing}

The plant and soil samples were collected 9 hours after the $\mathrm{N}$ labeling treatment. To avoid any bias due to $\mathrm{NO}_{3}{ }^{-}$transformation caused by microbial activity in the soil between the first and last pot collections, all pots were kept at $4{ }^{\circ} \mathrm{C}$ before their harvest. The aboveground parts and the roots of each individual were oven-dried at $70^{\circ} \mathrm{C}$ for $48 \mathrm{~h}$ and crushed with a ball mill mixer (Retch MM200 Eragny, France) for the 8 replicates. The 5 replicates with ${ }^{15} \mathrm{~N}$ addition were used (1) for plants, to determine the plant traits and the ${ }^{15} \mathrm{~N}$ concentrations in plants and (2) for rhizospheric soil (i.e., the soil under root influence), to analyze the microbial $\mathrm{N}$ activities and the microbial $\mathrm{N}$ abundances. The 3 replicates for the unlabeled pots were only used for the natural soil and plant ${ }^{15} \mathrm{~N}$ values.

For plants, individual aboveground and root parts were separately collected from each pot. The rhizospheric soil, considered as the remaining soil adhering to the roots after a manually shaking [25], was carefully sampled and was used for ${ }^{15} \mathrm{~N}$, soil (i.e., nitrate and ammonium concentrations) and microbial analysis (i.e., microbial activities and gene abundances). Nitrification and denitrification 
enzyme activity, as well as the nitrate and ammonium concentrations, were measured on fresh rhizospheric soil, and a subsample was immediately frozen at $-20{ }^{\circ} \mathrm{C}$ for the DNA extractions and gene abundance analysis.

\section{5. ${ }^{15} \mathrm{~N}$ Analysis}

Two mg of plant material was weighed to the nearest $0.1 \mathrm{mg}$ in tin capsules (i.e., the aboveground parts and the roots of each individual separately). The nitrogen concentration and isotope composition were measured using an elemental analyzer (Flash EA 1112, Thermo Scientific) coupled in a continuous flow with an isotope ratio mass spectrometer (Isoprime 100, Elementar, Lyon, France). Data were normalized using IAEA N-2, IAEA 305A and B international reference materials and expressed as ${ }^{15} \mathrm{~N}$ atom $\%\left({ }^{15} \mathrm{~N}\right.$ at $\left.\%={ }^{15} \mathrm{~N} /\left({ }^{14} \mathrm{~N}+{ }^{15} \mathrm{~N}\right) \times 100\right)[26]$.

${ }^{15} \mathrm{~N}$ uptake $\left(A^{15} \mathrm{~N}\right.$ in $\mu \mathrm{g} / \mathrm{g}$, hereafter called "nitrate assimilation") was calculated using:

$$
A^{15} \mathrm{~N}=\left({ }^{15} \mathrm{~N} \text { at } \%-{ }^{15} \mathrm{~N} \text { at } \% \text { control }\right) / 100 \times[\mathrm{N}] / 100 \times 10^{6}
$$

where ${ }^{15} \mathrm{~N}$ at $\%$ is the ${ }^{15} \mathrm{~N}$ atom\% of the sample, ${ }^{15} \mathrm{~N}$ at $\%$ control is the ${ }^{15} \mathrm{~N}$ atom $\%$ of the unlabeled sample, and $[\mathrm{N}]$ is the nitrogen concentration (\% dry weight).

We assessed the total amount of nitrate uptake in plants by calculating the ${ }^{15} \mathrm{~N}$ "accumulation":

$$
{ }^{15} \mathrm{~N} \text { “accumulation" }=A^{15} \mathrm{~N} \times M_{\text {plant }},
$$

where $M_{\text {plant }}$ is the plant dry mass. We obtained these results for the aboveground and root parts. Data for entire plants were calculated as follow:

$$
\begin{gathered}
\text { total }{ }^{15} \mathrm{~N} \text { accumulation }=\text { aboveground }{ }^{15} \mathrm{~N} \text { accumulation }+\operatorname{root}{ }^{15} \mathrm{~N} \text { accumulation } \\
{ }^{15} \mathrm{~N} \text { assimilation }=\text { total }{ }^{15} \mathrm{~N} \text { accumulation } / M \text { total } \text { plant }
\end{gathered}
$$

\subsection{Plant Traits}

We considered some plant functional traits, defined as "the characteristics of an organism that are considered relevant to its response to the environment and/or its effects on ecosystem functioning" [27]. At the end of the experiment, the plant height of all individuals was measured, and the leaves were numbered. Before crushing for ${ }^{15} \mathrm{~N}$ analysis, the dry aboveground and root parts of the plants were weighed to obtain aboveground biomass $(\mathrm{AB}$ ) and root biomass (RB). In our study, the root system was preferred to the belowground system (i.e., the whole system with the rhizome, their buds, and the roots), because the root system is more relevant to assess the impacts on the soil nitrogen cycle and the associated microbial $\mathrm{N}$ communities [28].

\subsection{Microbial Activity Measurements}

\subsubsection{Nitrification Enzyme Activity (NEA)}

To measure nitrification enzyme activity (NEA), $3 \mathrm{~g}$ of equivalent dry soil was incubated with $6 \mathrm{~mL}$ of $\left(\mathrm{NH}_{4}\right)_{2} \mathrm{SO}_{4}$ solution (50 $\mu \mathrm{g} \mathrm{N}-\mathrm{NH}_{4}{ }^{+} \cdot \mathrm{g}^{-1}$ dry soil), and distilled water was added to each sample to achieve $24 \mathrm{~mL}$ of total liquid volume in a flask [10]. The flasks were placed in a stirring oven at $28^{\circ} \mathrm{C}$ and $140 \mathrm{rpm}$. One milliliter of soil slurry was sampled after 2, 4, 6, 8, and $10 \mathrm{~h}$ of incubation, filtered at $0.2 \mu \mathrm{m}$ and stored in vials at $-20{ }^{\circ} \mathrm{C}$ until the $\mathrm{NO}_{2}{ }^{-}$and $\mathrm{NO}_{3}{ }^{-}$concentrations were measured using an ion chromatograph (ICS 900, Thermo Scientific ${ }^{\mathrm{TM}}$ Dionex $^{\mathrm{TM}}$, Salt Lake City, UT, USA). Nitrification was expressed in $\mu \mathrm{g}$ of $\mathrm{N}^{-\mathrm{NO}_{2}}{ }^{-}+\mathrm{N}^{-\mathrm{NO}_{3}}{ }^{-} \cdot \mathrm{h}^{-1} \cdot \mathrm{g}^{-1}$ of dry soil. 


\subsubsection{Denitrification Enzyme Activity (DEA)}

To measure denitrification enzyme activity (DEA), $10 \mathrm{~g}$ (equivalent dry weight) of fresh soil was placed in a flask hermetically sealed with a rubber stopper [29]. The atmosphere of the flasks was replaced by a $90 \%$ helium and $10 \%$ acetylene mixture to obtain anaerobic conditions and inhibit the nitrous oxide reductase that catalyzes the final step of denitrification, in which $\mathrm{N}_{2} \mathrm{O}$ is converted into $\mathrm{N}_{2}$. Distilled water $\left(2 \mathrm{~mL}\right.$ ) containing $\mathrm{KNO}_{3}\left(50 \mu \mathrm{g} \mathrm{N}-\mathrm{NO}_{3}{ }^{-} \cdot \mathrm{g}^{-1}\right.$ dry soil), glucose (500 $\mu \mathrm{g} \mathrm{C}$-glucose.g ${ }^{-1}$ dry soil), and glutamic acid ( $500 \mu \mathrm{g}$ C-glutamic acid ${ }^{-1}$ dry soil) was added through the rubber stopper using a syringe to ensure non-limiting amounts of carbon and $\mathrm{NO}_{3}{ }^{-}$for denitrification activity. The flasks were incubated at $28^{\circ} \mathrm{C}$ for $8 \mathrm{~h}$. After $2 \mathrm{~h}, \mathrm{~N}_{2} \mathrm{O}$ accumulation in the flask was measured every hour using a gas chromatograph ( $\mu$ GC R3000, SRA Instrument, Marcy L'Etoile, France). Denitrification was expressed in $\mu \mathrm{g}$ of $\mathrm{N}-\mathrm{N}_{2} \mathrm{O} \mathrm{g}^{-1}$ dry soil $\mathrm{h}^{-1}$.

\subsubsection{Soil Nitrate and Ammonium Concentrations}

Soil $\mathrm{NO}_{3}{ }^{-}$and $\mathrm{NH}_{4}{ }^{+}$concentrations were determined following extraction from soil subsamples with a solution of calcium chloride $\left(\mathrm{CaCl}_{2}\right)$ at $0.01 \mathrm{M}$, and $20 \mathrm{~mL}$ of calcium chloride was added to $5 \mathrm{~g}$ of equivalent dry mass soil. The soil was shaken at $140 \mathrm{rpm}$ for $2 \mathrm{~h}$ at $10^{\circ} \mathrm{C}$. The suspensions were filtered (Acrodisc Supor ${ }^{\circledR} \mathrm{PF}$ with membrane prefilter $0.8 / 0.2 \mu \mathrm{m}, \mathrm{VWR}$ ) and stored at $-20{ }^{\circ} \mathrm{C}$ before the amounts of $\mathrm{NO}_{3}{ }^{-}$and $\mathrm{NH}_{4}{ }^{+}$were measured by ionic chromatography described in Section 2.7.1.

\subsection{Microbial Abundance Measurements}

Soil DNA was extracted from $0.5 \mathrm{~g}$ of frozen soil using the FastDNA R Spin Kit for Soil (MPbio, Irvine, CA, USA) following the manufacturer's instructions. DNA concentrations were determined with the Quant-iT ${ }^{\mathrm{TM}}$ PicoGreen dsDNA Assay Kit (Invitrogen, Carlsbad, CA, USA). The abundances of the four microbial groups (ammonium-oxidizing bacteria and archaea and nitrite reductase genes) were determined by quantitative PCR (qPCR), targeting group-specific genes encoding key enzymes of the denitrification and nitrification pathways.

Abundances of ammonium-oxidizing bacteria $(\mathrm{AOB})$ and archaea $(\mathrm{AOA})$ were quantified based on the gene copy numbers present per gram of dry soil of the ammonium monooxygenase gene amo $A$ (for both bacteria and archaea). The $a m o A$ functional gene was amplified using the gene primers amoA_1F and amoA_2R for the AOB and CrenamoA616r and CrenamoA23f for the AOA, [30]. The abundances of denitrifying bacteria were measured based on the abundance of the nitrite reductase genes nirS and nirK. Fragments of the nirK and nirS genes encoding the copper and cd1 nitrite reductases, respectively, were amplified as described by [31]. Duplicate quantitative real-time PCR (qPCR) was carried out using SYBR green as the fluorescent dye on a Lightcycler 480 (Roche Diagnostics, Meylan, France). The efficiencies of all performed qPCRs were in the range of $90-99 \%$. The $\mathrm{R}^{2}$ values were always greater than 0.95 . The possible inhibition of PCR was tested in advance, and appropriate dilutions were chosen (data not shown).

\subsection{Statistical Analyses}

For all analyses, we excluded the 3 replicates for the unlabeled pots and we used the 5 replicates for the ${ }^{15} \mathrm{~N}$ labeled pots. We analyzed our data separately for the two types of soil to assess the impact of $F$. $\mathrm{x}$ bohemica on species and on the functioning depending on plant species. Differences in aboveground biomass, root biomass, nitrate assimilation and nitrate accumulation between species were analyzed with one-way ANOVAs on monocultures for both soil types. Effects of plant type (natives, invasive, and mixtures) on plant biomass, nitrification, and denitrification in the two types of soil were analyzed with Kruskal-Wallis tests. $n=5$ samples for invasive and $n=15$ samples for mixtures and native species. The effects of $F$. x bohemica on traits of H. lupulus, S. ebulus, or U. dioica are presented as the percent change in the mixture relative to the monoculture condition of this species (H-H, S-S, and U-U, respectively). Significant differences to 0 (i.e., $0 \%$, no effect of $\mathrm{F}$ on native species 
in mixture) were analyzed by Student's $t$-tests and differences between native species were analyzed by one-way ANOVAs in each soil. The effects of FF-FH-HH, FF-FS-SS, and FF-FU-UU on microbial activities and functional gene abundance were also tested by one-way ANOVA. Significant differences between means were tested by Tukey's multiple comparison tests $(p<0.05)$. The normality of residuals and homogeneity of variance were tested by Shapiro and Levene's tests, respectively. When necessary, data for microbial activities were squared root-transformed. Statistical analyses were performed with Jump Pro ${ }^{\circledR}$ software (v.13.2).

Other results beyond the scope of our article, i.e., a comparison of soil types on plant traits, or the effect of native species on $F$. $x$ bohemica, are shown without comments in the supplementary materials (Table S2 and Figures S1 and S2).

\section{Results}

\subsection{Comparison between Species for Growth and N Management in Plants}

In low nitrate conditions, the aboveground biomass of monocultures were not different $(p=0.255)$, while in high nitrate conditions, F obtained higher aboveground biomass than the three other species (Figure 1A, $p<0.001)$. For roots, both in low $(p=0.009)$ and in high $(p=0.039)$ nitrate conditions, $\mathrm{U}$ showed the highest biomass and $\mathrm{S}$ showed the lowest (Figure 1B). In the $\mathrm{NO}_{3}{ }^{-}$poor environment, the nitrate assimilation rate was not different between species $(p=0.163)$. In the $\mathrm{NO}_{3}{ }^{-}$rich environment, $\mathrm{U}$ showed the highest assimilation rate and $\mathrm{S}$ showed the lowest (Figure $1 \mathrm{C}, p=0.034$ ). The accumulation of labeled nitrate was higher in $\mathrm{U}$ in $\mathrm{NO}_{3}{ }^{-}$poor soil $(p=0.008)$ and in $\mathrm{F}$ compared to $\mathrm{S}$ in $\mathrm{NO}_{3}{ }^{-}$rich soil (Figure 1D).
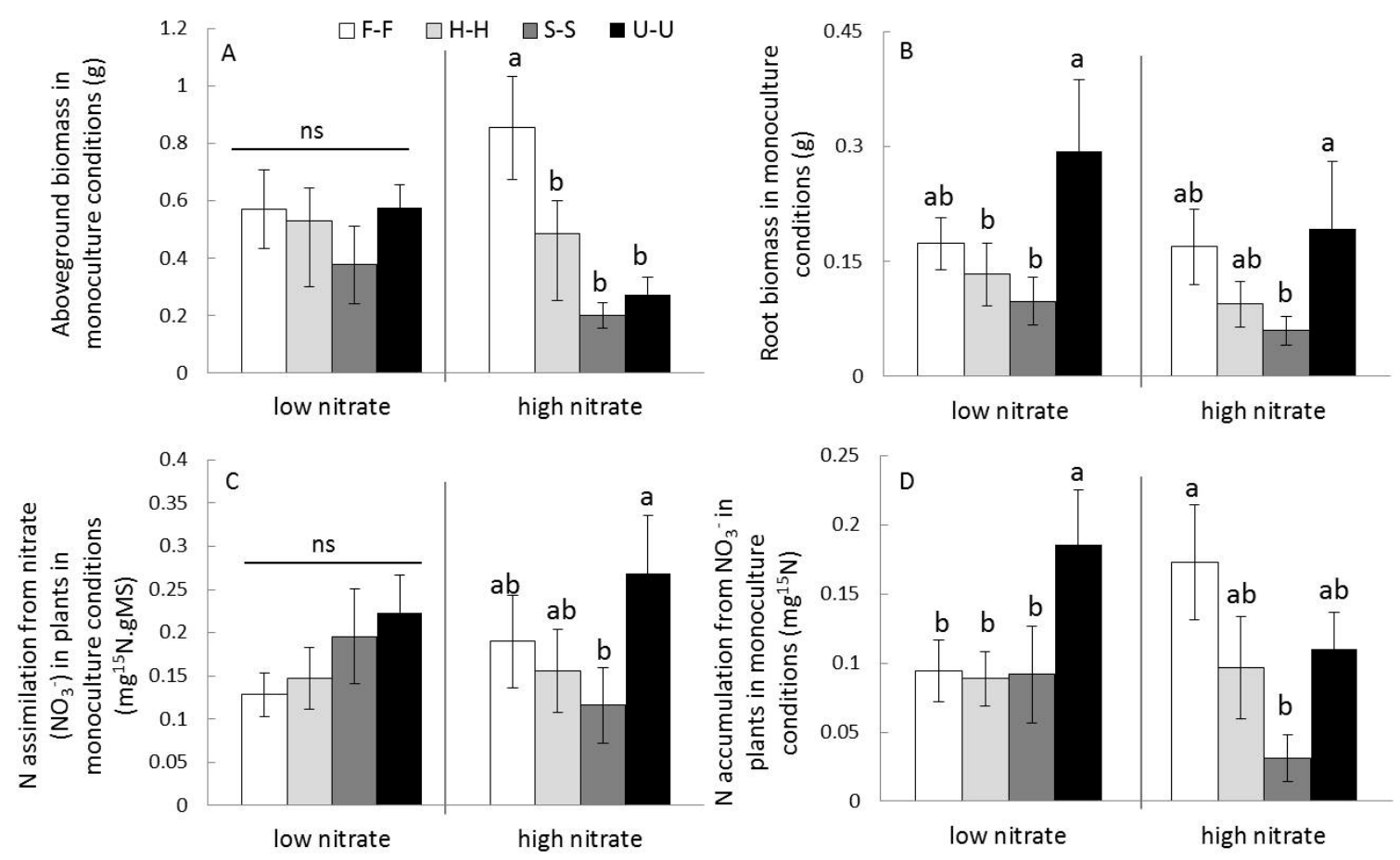

Figure 1. Aboveground biomass (A), root biomass (B), $\mathrm{N}$ assimilation from nitrate $\left(\mathrm{NO}_{3}{ }^{-}\right)$in plants (C) and $\mathrm{N}$ accumulation from $\mathrm{NO}_{3}{ }^{-}$in plants (D) in invasive and native monoculture conditions in two soils (one with a low soil nitrate concentration and one with a high soil nitrate concentration). Mean and standard error are presented here. $n=5$ for each plant competition and for each soil type. 


\subsection{Impacts of F. $x$ bohemica on Native Plants for both Soil Types (Low or High Nitrate Conditions)}

\subsubsection{Impacts on Aboveground Traits and Root Biomass}

F had contrasting effects on the three native plant species in both soils (Figure 2). F. x bohemica decreased root biomass ( $p=0.0016 ;-43 \%$ in average), aboveground biomass ( $p=0.022,-44 \%$ ), and leaf number $(p=0.005,-38 \%)$ of H. lupulus in low $\mathrm{NO}_{3}{ }^{-}$conditions and height $(p=0.005,-17 \%)$ in high $\mathrm{NO}_{3}{ }^{-}$conditions. Root biomass of $\mathrm{H}$. lupulus in $\mathrm{NO}_{3}{ }^{-}$rich soil, on the contrary, showed a significant increase in the presence of F. $\mathrm{x}$ bohemica $(p=0.05,69 \%)$. S. ebulus was negatively impacted by $F . x$ bohemica in mixture. The species showed significant decreases in aboveground biomass $(p=0.0028$, $-41 \%$ in average) and height $(p=0.0007,-24 \%)$ in low $\mathrm{NO}_{3}{ }^{-}$conditions; and in root biomass $(0.0045$, $-88 \%)$ and aboveground biomass $(p=0.0013,-50 \%)$ in high $\mathrm{NO}_{3}{ }^{-}$. The only species showing an increase of performances in low nitrate conditions was $U$. dioica with significant increases in its height ( $p=0.034,22 \%$ on average) and its aboveground biomass $(p=0.0217,28 \%)$ in mixture with F. $\mathrm{x}$ bohemica . In $\mathrm{NO}_{3}{ }^{-}$rich soil, $U$. dioica had $34 \%$ more leaves in mixtures compared to its monoculture.
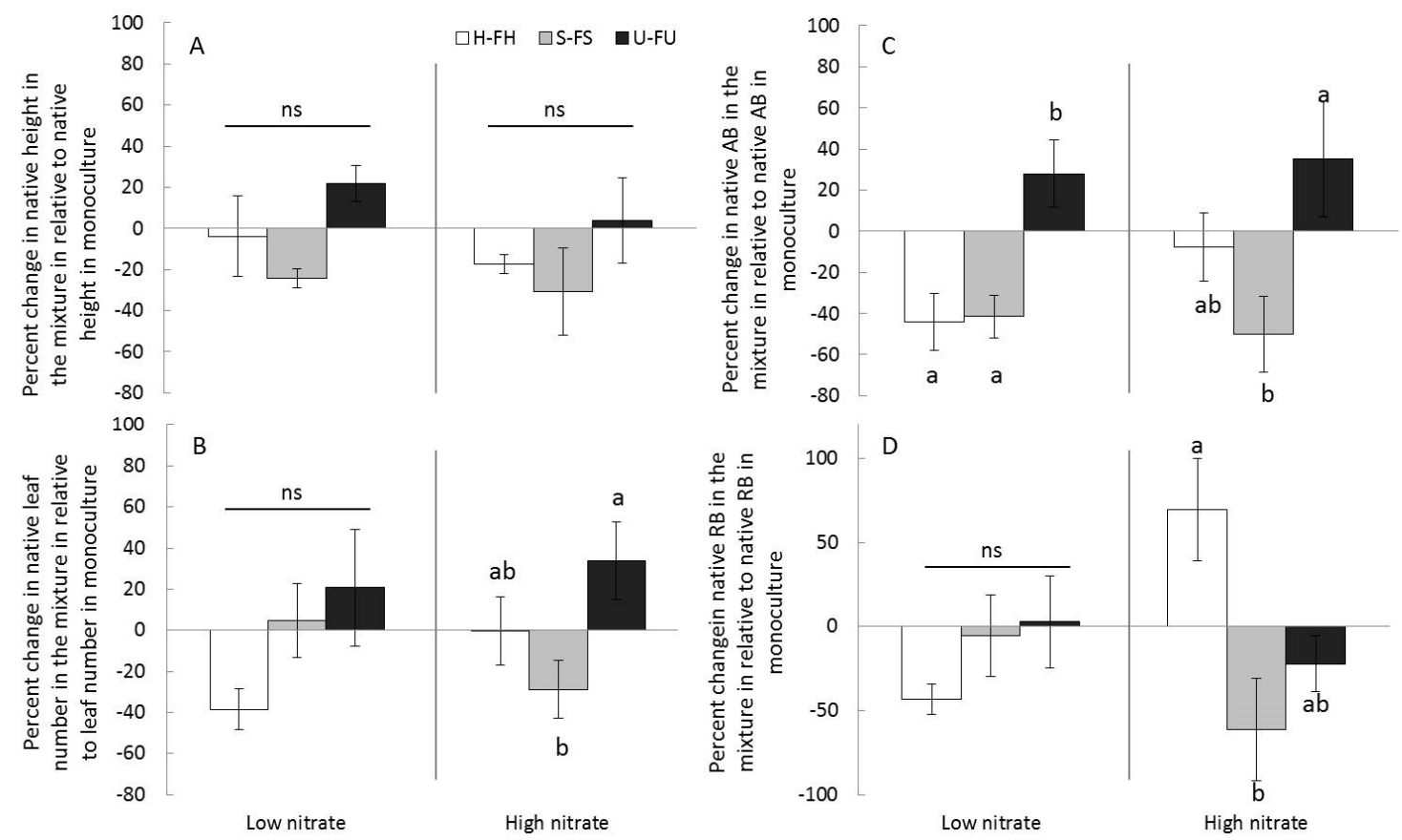

Figure 2. Effects of F. $\mathrm{x}$ bohemica on traits of native species expressed as the percent change in the mixture relative to the native monoculture (A: percent change in plant height; $\mathbf{B}$ : in leaf number; $\mathbf{C}$ : in aboveground biomass (AB); D: in root biomass (RB)). Negative values indicate a negative effect of $F$ on the native species in the mixture (values of traits of the species in the mixture are inferior to the values in the monocultures), and positive values indicate a positive effect of $F$ on the native species in the mixture. Different letters indicate a significant difference $(p<0.05)$ between mixtures for each variable. Mean and standard error are presented here. $n=5$ for each plant competition and for each soil type.

While $\mathrm{H}$ and $\mathrm{S}$ were negatively affected compared to their monocultures, $\mathrm{U}$ showed higher aboveground biomass in both $\mathrm{NO}_{3}{ }^{-}$poor and $\mathrm{NO}_{3}{ }^{-}$rich soils compared to other native species ( $p=0.018$ and $p=0.05$ for low and high nitrate conditions compared to $\mathrm{H}$ and $\mathrm{S}$, respectively; Figure 2C). For root biomass, significant changes between native species were found only for $\mathrm{NO}_{3}{ }^{-}$rich soil. $\mathrm{H}$ root biomass showed a large increase in mixture with F compared to S-FS and U-FU mixtures ( $p=0.0095$; Figure 2D). For morphological traits, no significant differences in the effect of F. $\mathrm{x}$ bohemica on height were found between species (Figure 2A), while for leaf number, in $\mathrm{NO}_{3}{ }^{-}$rich soil, $\mathrm{U}$ was found to have more leaves in the mixture compared to its monoculture ( $p=0.05$; Figure $2 \mathrm{~B}$ ). 


\subsubsection{Impacts on Plant $N$ Uptakes}

No significant differences were found between the responses of each native species to their mixtures with $\mathrm{F}$ in terms of assimilation rates and nitrate accumulation (Figure 3A,B). However, we observed a significant effect of the presence of $F$. $x$ bohemica on species nitrate assimilation and accumulation compared to their monocultures (i.e., when the percentage is significantly different from $0)$. While nitrate assimilation of H. lupulus was not impacted compared to the other natives, its nitrate accumulation decreased in low nitrate conditions $(p=0.0413,-50 \%)$, following its decrease in biomass (Figure 2). In low nitrate conditions, $\mathrm{U}$ and $\mathrm{S}$ were found to have a significant decrease for assimilation rates ( $p=0.019,-26 \%$ on average and $p<0.0001,-44 \%$, respectively for $\mathrm{U}$ and $\mathrm{S})$. For $\mathrm{NO}_{3}{ }^{-}$rich soil, only significant effects were found in nitrate accumulation for $S(p=0.0006,-88 \%)$.
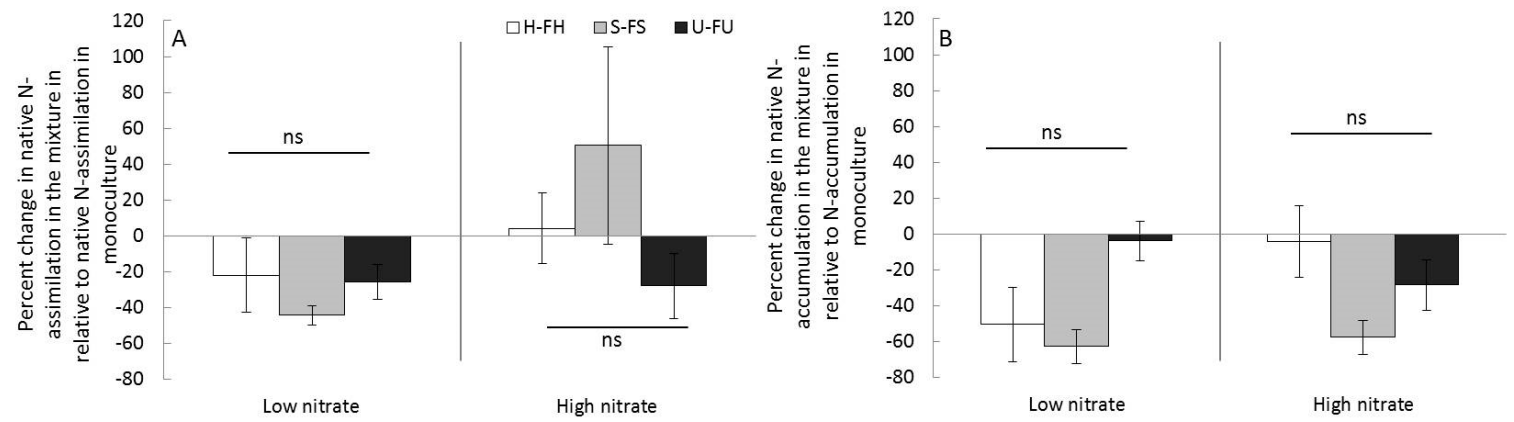

Figure 3. Effects of F. $x$ bohemica on native species $N$ uptake expressed as the variation in the mixture relative to the native monoculture (A: total $\mathrm{N}$ assimilation in the plant; $\mathbf{B}$ : total $\mathrm{N}$ accumulation in the plant). Different letters indicate a significant difference $(p<0.05)$ between mixtures for each variable. Mean and standard error are presented here. $n=5$ for each plant competition and for each soil type.

3.3. Effects of Plant Type on Plant Biomass and Potential Rates of Nitrification and Denitrification in the Two Types of Soil

\subsubsection{Effects on Plant Biomass}

With low $\mathrm{NO}_{3}{ }^{-}$concentrations, no change in root biomass was found between invasive, native, and mixed cultures (Table 1a). With high nitrate conditions, significant differences were found (1) between natives and mixtures for root biomass with highest root biomass for invasive and mixtures, and (2) in aboveground parts $(p<0.0001$, Table $1 \mathrm{~b})$ with the lowest aboveground biomass for native species.

Table 1. Effect of soil type (low (a) or high (b) soil nitrate conditions) and plant type (invasive, native, or mixed) on aboveground biomass and root biomass. Mean and standard error are presented here. $n=5$ samples for invasive and $n=15$ samples for mixtures and native species for each soil type. The results from Kruskal-Wallis tests are presented here with the $p$-value; when the test is significant, the nonparametric pair comparisons are shown.

\begin{tabular}{cccccccc}
\hline & \multicolumn{3}{c}{ Plant Treatments } & \multicolumn{3}{c}{ Non-Parametic Variance Analysis } \\
\cline { 2 - 7 } & Invasive & Mixture & Natives & $p$-Value & I vs. M & I vs. N & M vs. N \\
\hline $\begin{array}{c}\text { (a) low nitrate } \\
\text { Aboveground biomass }\end{array}$ & $1.08 \pm 0.11$ & $1.05 \pm 0.08$ & $0.96 \pm 0.08$ & ns & - & - & - \\
$\quad$ Root biomass & $0.34 \pm 0.02$ & $0.35 \pm 0.04$ & $0.35 \pm 0.06$ & ns & - & - & - \\
$\quad$ (b) high nitrate & & & & & & & \\
Aboveground biomass & $1.71 \pm 0.26$ & $1.39 \pm 0.08$ & $0.64 \pm 0.09$ & $<0.0001$ & - & 0.0003 & 0.0001 \\
$\quad$ Root biomass & $0.34 \pm 0.04$ & $0.31 \pm 0.02$ & $0.23 \pm 0.05$ & 0.0212 & - & - & 0.0101 \\
\hline
\end{tabular}

\subsubsection{Effects on Nitrification and Denitrification}

Plant type had significant effects on NEA, although these effects varied with soil type (Figure 4A). While NEA increased in the mixture compared to that in the native species in soil with low $\mathrm{NO}_{3}{ }^{-}$ 
concentrations $\left(X^{2}=6.25 ; p=0.04\right)$, NEA decreased in the mixture and native species groups compared to that in the invasive species in soil with high $\mathrm{NO}_{3}{ }^{-}$concentrations $\left(X^{2}=8.12 ; p=0.02\right)$. We found significant negative effects on the DEA of invasive species monocultures or mixtures compared to the native species monocultures (Figure $4 \mathrm{~B})$ but only in soil with high $\mathrm{NO}_{3}{ }^{-}$concentrations $\left(\mathrm{X}^{2}=16.9\right.$; $p=0.0002)$.
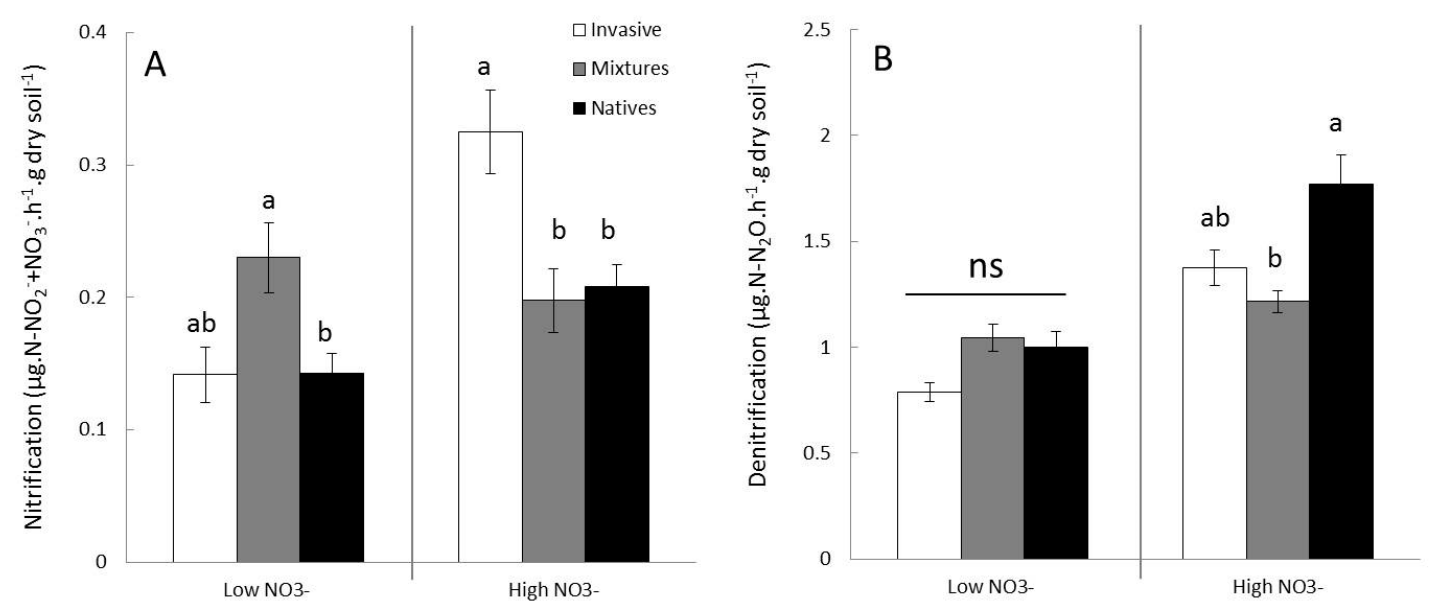

Figure 4. Effect of soil type (low or high soil nitrate concentrations) and plant type (invasive, native, or mixture) on microbial parameters ([A] nitrification enzyme activity (NEA) and [B] denitrification enzyme activity (DEA)). Mean and standard error are presented here. $n=5$ samples for invasive and $n=15$ samples for mixtures and native species for each soil type.

\subsection{Effects of Competition Treatments on Soil Functioning (Nitrification and Denitrification) in Terms of Microbial Activities and Gene Abundances}

Only a few effects on soil functioning were found in soils with low $\mathrm{NO}_{3}{ }^{-}$concentrations. No change in nitrification or denitrification was found with the comparison of $\mathrm{F}$ and $\mathrm{H}$ activities (Figure 5A,D) and gene abundances (Table 2), and the same results were found for the comparison between $\mathrm{F}$ and $\mathrm{U}$ (Figure 5C,F and Table 2). However, significant effects were found on NEA in the mixture of $\mathrm{F}$ and $\mathrm{S}$ $(p=0.025$; Figure 5B), AOA ( $p=0.023$, Table 2$), \operatorname{nirK}(p=0.033$; Table 2$)$ and nirS $(p=0.004$; Table 2$)$. Soil with F-F and S-S had a significantly lower nitrification rate than that of the soil planted with F-S $(p=0.036$ and $p=0.051$, respectively, Figure 5B). The same pattern was found for AOA ( $p=0.029$ and $p=0.056$ for comparisons of F-S vs. F-F and F-S vs. S-S, respectively) and for nirS ( $p=0.005$ and $p=0.013$ for F-S vs. F-F and F-S vs. S-S, respectively). For nirK, gene abundance was significantly higher under F-S than under S-S $(p=0.03)$.

Stronger effects on soil functioning were found in soils with high nitrate concentrations. NEA was reduced when the invasive species competed with two native species (Figure 5A, F-F and F-H comparison, $p=0.0018$ and Figure 5C, F-F and F-U comparison, $p=0.005)$, but this pattern was not observed for $\mathrm{S}$ (Figure $5 \mathrm{~B}$ ). The results on the nitrifying gene abundances showed the same pattern as NEA only for $\mathrm{U}$, where AOA and AOB were more abundant in F-F than in F-U ( $p=0.011$ and $p=0.01$, respectively). In this case, NEA and the associated functional genes were significantly correlated (linear regression between NEA and AOA, $\mathrm{R}^{2}=0.38, p=0.014$ and linear regression between NEA and AOB, $\left.\mathrm{R}^{2}=0.34, p=0.023\right)$. The AOB was found to be significantly lower in the S-S treatment than in the F-F treatment (Table 2, $p=0.013$ ). For DEA, only S-S and U-U showed a tendency to increase compared to F-F (Figure 5E,F; $p=0.078$ and $p=0.065$, respectively). For H, DEA was higher in $\mathrm{H}-\mathrm{H}$ than in $\mathrm{F}-\mathrm{H}$ (Figure $5 \mathrm{D}, p=0.008$ ). No significant effect was found on denitrifying genes in the comparison between invasive and native species. 

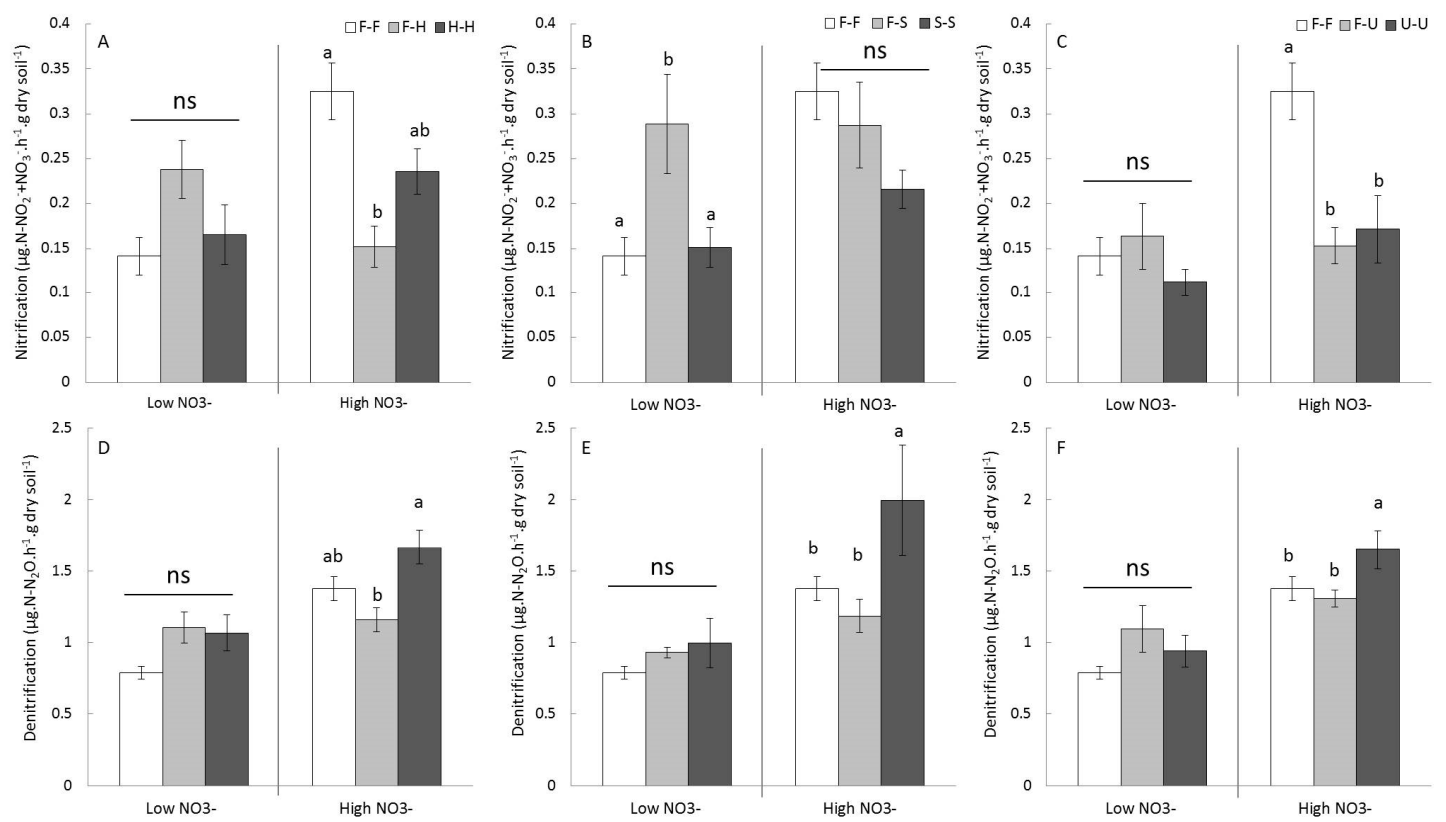

Figure 5. Impacts of plant competition between Fallopia $x$ bohemica $(\mathrm{F})$ and native species, including Humulus lupulus (H; A and D); Sambucus ebulus (S; B and E); and Urtica dioica (U; C and F) on microbial activities (nitrification enzyme activity: NEA, and denitrification enzyme activity: DEA) for two soils (one with a low soil nitrate concentration and one with a high soil nitrate concentration). Mean and standard errors are presented here. $n=5$ for each plant competition and for each soil type.

Table 2. Effects of competition treatments on nitrifying (copy numbers of ammonia-oxidizing bacteria $(\mathrm{AOB})$ and archaea (AOA)) and denitrifying (copy numbers of $\mathrm{Cu}$ nitrite reductors nirK and nirS) gene abundances for two soils (a: with low nitrate concentrations and b: high nitrate concentrations). Mean and standard errors are shown; $n=5$. The results of one-way ANOVA are presented with $p$-values when $p<0.05$ (ns: non-significant).

\begin{tabular}{|c|c|c|c|c|c|}
\hline \multirow[b]{2}{*}{ (a) Low nitrate } & & \multicolumn{3}{|c|}{ Plant Conditions } & \multirow{3}{*}{$\begin{array}{c}\begin{array}{c}\text { Variance } \\
\text { Analysis }\end{array} \\
\begin{array}{c}p \text {-value } \\
\text { ns }\end{array}\end{array}$} \\
\hline & & FF & $\mathrm{FH}$ & $\mathrm{HH}$ & \\
\hline & Ammonia-oxidizing bacteria $\left(10^{6}\right.$ copy per $\mathrm{g}$ of dry soil) & $4.2 \pm 0.2$ & $5.0 \pm 0.3$ & $5.2 \pm 1$ & \\
\hline & Ammonia-oxidizing archea $\left(10^{7}\right.$ copy per g of dry soil) & $8.6 \pm 0.5$ & $9.2 \pm 0.6$ & $6.7 \pm 1.3$ & ns \\
\hline & nirK ( $10^{7}$ copy per $\mathrm{g}$ of dry soil) & $2.6 \pm 0.2$ & $2.6 \pm 0.2$ & $3.4 \pm 0.5$ & ns \\
\hline & nirs $\left(10^{6}\right.$ copy per $g$ of dry soil $)$ & $5.4 \pm 0.2$ & $6.5 \pm 0.6$ & $9.5 \pm 2.7$ & ns \\
\hline & & FF & FS & SS & $p$-value \\
\hline & Ammonia-oxidizing bacteria $\left(10^{6}\right.$ copy per $g$ of dry soil) & $4.2 \pm 0.2$ & $4.5 \pm 0.2$ & $4.3 \pm 0.5$ & ns \\
\hline & Ammonia-oxidizing archea $\left(10^{7}\right.$ copy per g of dry soil) & $8.6 \pm 0.5$ & $10 \pm 0.4$ & $6.6 \pm 0.3$ & 0.023 \\
\hline & nirK $\left(10^{7}\right.$ copy per $\mathrm{g}$ of dry soil $)$ & $2.6 \pm 0.2$ & $3.2 \pm 0.1$ & $2.4 \pm 0.2$ & 0.033 \\
\hline & nirS $\left(10^{6}\right.$ copy per g of dry soil $)$ & $5.4 \pm 0.2$ & $6.7 \pm 0.2$ & $5.6 \pm 0.3$ & 0.004 \\
\hline & & FF & FU & UU & $p$-value \\
\hline & Ammonia-oxidizing bacteria ( $10^{6}$ copy per $g$ of dry soil) & $4.2 \pm 0.2$ & $3.7 \pm 0.2$ & $4.1 \pm 0.3$ & ns \\
\hline & Ammonia-oxidizing archea $\left(10^{7}\right.$ copy per g of dry soil) & $8.6 \pm 0.5$ & $8.9 \pm 0.4$ & $9.3 \pm 0.7$ & ns \\
\hline & nirK $\left(10^{7}\right.$ copy per $\mathrm{g}$ of dry soil $)$ & $2.6 \pm 0.2$ & $2.4 \pm 0.1$ & $2.6 \pm 0.1$ & ns \\
\hline & nirs $\left(10^{6}\right.$ copy per g of dry soil $)$ & $5.4 \pm 0.2$ & $7.2 \pm 0.9$ & $5.6 \pm 0.2$ & ns \\
\hline \multirow[t]{15}{*}{ (b) High nitrate } & & FF & $\mathrm{FH}$ & $\mathrm{HH}$ & $p$-value \\
\hline & Ammonia-oxidizing bacteria ( $10^{6}$ copy per $g$ of dry soil) & $8.0 \pm 0.4$ & $7.3 \pm 0.6$ & $5.5 \pm 1.4$ & ns \\
\hline & Ammonia-oxidizing archea $\left(10^{7}\right.$ copy per g of dry soil) & $2.5 \pm 0.1$ & $2.3 \pm 0.1$ & $1.6 \pm 0.4$ & ns \\
\hline & nirK $\left(10^{7}\right.$ copy per g of dry soil $)$ & $5.1 \pm 0.5$ & $4.3 \pm 0.1$ & $3.7 \pm 0.7$ & ns \\
\hline & nirS $\left(10^{6}\right.$ copy per $g$ of dry soil $)$ & $24.4 \pm 1.3$ & $21.1 \pm 1.1$ & $18.2 \pm 4.5$ & ns \\
\hline & & FF & FS & SS & $p$-value \\
\hline & Ammonia-oxidizing bacteria ( $10^{6}$ copy per $g$ of dry soil) & $8.0 \pm 0.4$ & $6.6 \pm 0.4$ & $5.9 \pm 0.5$ & 0.013 \\
\hline & Ammonia-oxidizing archea ( $10^{7}$ copy per $g$ of dry soil) & $2.5 \pm 0.1$ & $6.6 \pm 0.5$ & $5.9 \pm 0.6$ & ns \\
\hline & nirK $\left(10^{7}\right.$ copy per $g$ of dry soil $)$ & $5.1 \pm 0.5$ & $6.6 \pm 0.6$ & $5.9 \pm 0.7$ & ns \\
\hline & nirS $\left(10^{6}\right.$ copy per g of dry soil $)$ & $24.4 \pm 1.3$ & $6.6 \pm 0.7$ & $5.9 \pm 0.8$ & ns \\
\hline & & FF & FU & UU & $p$-value \\
\hline & Ammonia-oxidizing bacteria ( $10^{6}$ copy per $g$ of dry soil) & $8.0 \pm 0.4$ & $5.7 \pm 0.4$ & $5.7 \pm 0.5$ & 0.005 \\
\hline & Ammonia-oxidizing archea $\left(10^{7}\right.$ copy per g of dry soil) & $2.5 \pm 0.1$ & $1.9 \pm 0.1$ & $2.0 \pm 0.1$ & 0.01 \\
\hline & nirK $\left(10^{7}\right.$ copy per $\mathrm{g}$ of dry soil $)$ & $5.1 \pm 0.5$ & $4.5 \pm 0.4$ & $4.8 \pm 0.2$ & ns \\
\hline & nirs $\left(10^{6}\right.$ copy per $g$ of dry soil $)$ & $24.4 \pm 1.3$ & $20.0 \pm 1.6$ & $21.2 \pm 0.9$ & ns \\
\hline
\end{tabular}




\section{Discussion}

\subsection{Impact of Knotweed on Competing Species: From Little Negative Effect to Facilitation}

The comparison of monocultures of the four species showed contrasting strategies between the species, especially between $F$. x bohemica and U. dioica. More than the other species, F. x bohemica was able to produce high aboveground biomass in a nitrate-rich environment, and thus, although its assimilation rate was not significantly different than that of the other species, it was able to accumulate the highest amount of labeled nitrate in $\mathrm{NO}_{3}{ }^{-}$rich soil. These results in natural soils are consistent with recent findings [32], who showed that Japanese knotweeds did not have a better nitrogen uptake efficiency than that of native species but had a better nitrogen use efficiency (i.e., the biomass produced due to the uptake of nitrogen). On the other hand, $U$. dioica showed the highest root biomass, especially in low nitrate soil, and the highest nitrate assimilation rate. This resulted in a better nitrate accumulation in poor environments.

From these findings, we could expect that $F$. x bohemica affected the other species by better competing for resources, especially in $\mathrm{NO}_{3}{ }^{-}$rich soil; in contrast, $U$. dioica was more efficient in poor soil. The results indeed showed that the impact of the presence of $F . x$ bohemica on the native species performance in the mixture depended on the species. S. ebulus was either negatively affected or not affected. In $U$. dioica, we observed more aboveground biomass and a greater number of leaves in mixtures with $F . x$ bohemica than that in monocultures. H. lupulus was globally negatively affected, except for an increase in root biomass only in high nitrate conditions. To our knowledge, this study is the first observation of facilitation induced by F. $\mathrm{x}$ bohemica in vascular species. However, these results should be considered with caution, given the number of published studies (experiments and in situ) that have found only negative effects of Fallopia spp. on the biomass of competing species (see [20]). We did not find a satisfactory explanation of the pattern on root biomass in H. lupulus. However, the literature already noted that $U$. dioica (1) could outcompete $F$. japonica (even if the relative yield of $U$. dioica was decreased by competition with F. japonica) [33], (2) is a strong competitor [34] and (3) is one of the few species able to coexist in Fallopia spp. stands [35,36]. Moreover, U. dioica was shown to be able to store nitrogen in its belowground organs (i.e., rhizomes and roots) as nitrate and/or amino acids (i.e., asparagin and arginin) forms [37]. U. dioica also exhibited a high nitrate reductase activity, as well as Fallopia japonica [38]. All these results may indicate that $F$. $x$ bohemica and $U$. dioica have competing nitrogen acquisition strategies, but that their niches are sufficiently different to allow coexistence, depending on environmental conditions. This hypothesis would require more investigations to be confirmed.

\subsection{Impacts of knotweed on Soil N-Functions and Microbial Communities: The Surprising Case of $\mathrm{NO}_{3}{ }^{-}$Poor Soil}

Unexpectedly, only a few significant impacts of $F$. $\mathrm{x}$ bohemica in mixtures with native species were found on nitrifying and denitrifying communities and soil functioning under low nitrate conditions. Generally, soils with low mineral-N content are expected to be strongly influenced by plant-microorganism competition. Cantarel et al. [28] showed that an increase in mineral-N soil content (by fertilization) can partially release the effects of plants on microbial $\mathrm{N}$ activities and supported the hypothesis that plants impact microbial $\mathrm{N}$ communities via competition for $\mathrm{N}$. Moreover, F. $\mathrm{x}$ bohemica is known to be (1) a very good competitive species [18,39] and (2) tolerant to various environmental conditions, from low to high nutrient soils [40]. We supposed that this tolerance to low nitrate conditions came from its ability to drive the nitrogen cycle resulting in more available nitrates and, more particularly, its ability to inhibit denitrification (BDI [11]). Moreover, in its native area, Fallopia spp. has been shown to influence the soil $\mathrm{N}$ cycle in increasing the concentration of soil $\mathrm{N}$, during the local growth of the patch, accumulating in organic and mineral forms [41,42]. The conservation of nitrogen appears to be an adaptation to its native ecosystem. All of these results suggest that the most significant results on the $\mathrm{N}$ cycle would occur in low nitrate conditions. However, contrary 
to our expectations, only one significant difference occurred in low nitrate conditions: nitrification and copy number of ammonia-oxidizing archaea (AOA) increased in the F-S mixture compared to the S. ebulus and F. $x$ bohemica monocultures. AOA is predominant in our soils, as often found in the rhizosphere [43], because of the higher AOA affinity for oxygen or carbon dioxide [44]. We also found that denitrifying gene abundances (i.e., nirK and nirS) were more abundant in the F-S mixture than in the $\mathrm{F}$ and $\mathrm{S}$ monocultures, without a change in denitrification. This result could reflect differences in microbial nitrite reductase community efficiency or phenotypic changes with faster or higher microbial turnover for denitrifying communities but lower efficiency for their nitrate/nitrite metabolism [45]. Overall, these results showed that competition between plants and nitrifying communities seemed to be released when S. ebulus was present in the mixture, suggesting an increase in nitrate produced by nitrification. However, denitrification was not affected, suggesting that some of the produced nitrates were used by plants. S. ebulus was strongly impacted by the presence of $F$. $x$ bohemica in the mixture, with a large decrease in nitrate absorption and accumulation (more than $50 \%$ ) in favor of Japanese knotweed assimilation and accumulation (Figure S2). One of the key results in $\mathrm{NO}_{3}{ }^{-}$poor soil was the finding of no effect of $F$. $x$ bohemica and/or mixtures on denitrification. Japanese knotweed is known to have the capacity to inhibit soil denitrification $[10,11]$ by the production of plant metabolites (i.e., procyanidins; $[46,47])$. However, under low nitrate conditions, we did not find any change in denitrification rates between $F$. x bohemica and native species. Procyanidins are known to be complex polymeric polyphenols [48] that are potentially costly for F. $x$ bohemica in limited nitrate conditions and are thus produced less in stressful conditions or are dependent on the developmental stage of the plants. Another explanation could be that produced procyanidins were ineffective in our experimental conditions because, for instance, they were sorbed into the soil or degraded.

\subsection{Impacts of Knotweed on Soil N-Functions and Microbial Communities: $\mathrm{NO}_{3}{ }^{-}$Rich Soil, Ideal Playground for Knotweed?}

In $\mathrm{NO}_{3}{ }^{-}$rich soil, nitrification was generally found to be reduced under mixtures and monocultures of natives, except for S. ebulus. This decrease was followed by a decrease in the nitrifying bacterial abundance of $H$. lupulus and in the nitrifying bacterial and archaeal abundances of $U$. dioica. All these modifications of the nitrification process and nitrifier communities could be seen as a mechanism implied in the niche construction of the native species following the arrival of an invasive species, which induced changes in the niche construction of native plant species and of the nitrifying community.

In our experiment, denitrification was always reduced in mixture conditions compared to native monoculture conditions, suggesting that $F . x$ bohemica can set up the biological inhibition of denitrification (BDI), regardless of the native plant associated with F. $x$ bohemica. BDI is known to increase soil $\mathrm{NO}_{3}{ }^{-}$availability in soil $[46,49]$. Here, we found that only the growth and $\mathrm{N}$ accumulation of knotweed were impacted by the BDI in mixtures, with a higher biomass of $F$. $x$ bohemica than that of native species. These results highlighted that the effect of procyanidins was beneficial for plant procyanidin producers and that F. $\mathrm{x}$ bohemica took advantage of soil nitrate not used by microorganisms following the BDI. The decrease in DEA was never coupled to the abundances of denitrifiers (nirK and nirS). These results suggest that the denitrification modifications induced by Japanese knotweed are weakly mediated by changes in the abundance of the denitrifying community, as already found by [10]. We provide evidence that changes in microbial activity can occur independently of changes in associated functional gene abundances, as found for nitrifying and denitrifying microbial composition [50]. Because of the relative stability of the microbial $\mathrm{N}$ community structure, investigations in RNA-based analyses would be required for future studies in invaded/non-invaded regions, as microbial functioning indicators of plant-microbe competition for $\mathrm{N}$-substrates.

\section{Conclusions}

Our results highlight that in $\mathrm{NO}_{3}{ }^{-}$rich soil conditions, the invasive species F. $\mathrm{x}$ bohemica showed higher aboveground biomass and $\mathrm{N}$ accumulation than the three native species that were studied. In the 
presence of $F$. $x$ bohemica (in its monoculture or in mixtures), denitrification was reduced compared to the soils with native monocultures, suggesting that $F . x$ bohemica captures a part of the soil nitrate for its own growth to the detriment of the denitrifying microbial community and native plant species growth. In contrast, very few impacts on soil $\mathrm{N}$ functioning were found in $\mathrm{NO}_{3}{ }^{-}$poor soil, suggesting that its control on the activity and abundance of the microorganisms involved in denitrification may be less pronounced than previously expected or hidden by other processes.

Supplementary Materials: The following are available online at http://www.mdpi.com/1424-2818/12/4/156/s1, Table S1: Localization of plant populations, Table S2: Results on the effect of soil type on plant traits, Figure S1: Effects of native species on traits of $F . x$ bohemica expressed as a percent change in the mixture relative to the invasive monoculture, Figure S2: Effects of mixtures on $\mathrm{N}$ uptake of F. x bohemica expressed as a percent change in the mixture relative to the invasive species in monocultures.

Author Contributions: Conceptualization, A.A.M.C., S.R. and F.P.; data curation, A.A.M.C. and S.R.; formal analysis, A.A.M.C. and S.R.; funding acquisition, S.R. and F.P.; project administration, A.A.M.C., S.R., and F.P.; supervision, A.A.M.C., S.R., and F.P.; validation, A.A.M.C. and S.R.; visualization, A.A.M.C.; writing-original draft, A.A.M.C. and S.R.; writing-review and editing, A.A.M.C., S.R., L.S., and F.P.; investigation, A.A.M.C., S.R., L.S., J.B., J.G., L.B., S.P., C.C.d.C., and F.P.; methodology, A.A.M.C., S.R., L.S., J.G., and F.P.; resources, A.A.M.C., S.R., and L.S. All authors have read and agreed to the published version of the manuscript.

Funding: This research was funded by FEDER-Plan Loire Grandeur Nature, Région Auvergne-Rhône-Alpes, Département de la Loire, Agence de l'eau Loire-Bretagne, and the FR BioEnvis - Université Lyon 1.

Acknowledgments: The authors want to thank FEDER-Plan Loire Grandeur Nature, Région Auvergne-RhôneAlpes, Département de la Loire, Agence de l'eau Loire-Bretagne, and FR BioEnvis (Université Lyon 1) for financial support and Félix Vallier and Anne-Kristel Bittebière for technical help.

Conflicts of Interest: The authors declare no conflict of interest. The funders had no role in the design of the study; in the collection, analyses, or interpretation of data; in the writing of the manuscript, or in the decision to publish the results.

\section{References}

1. Ricciardi, A.; Hoopes, M.F.; Marchetti, M.P.; Lockwood, J.L. Progress toward understanding the ecological impacts of nonnative species. Ecol. Monogr. 2013, 83, 263-282. [CrossRef]

2. Harcombe, P.; Cameron, G.N.; Glumac, E.G. Above-ground net primary productivity in adjacent grassland and woodland on the coastal prairie of Texas, USA. J. Veg. Sci. 1993, 4, 521-530. [CrossRef]

3. Lett, M.S.; Knapp, A.K.; Briggs, J.M.; Blair, J.M. Influence of shrub encroachment on aboveground net primary productivity and carbon and nitrogen pools in a mesic grassland. Can. J. Bot. 2004, 82, 1363-1370. [CrossRef]

4. Wilsey, B.J.; Polley, H.W. Aboveground productivity and root-shoot allocation differ between native and introduced grass species. Oecologia 2006, 150, 300-309. [CrossRef] [PubMed]

5. Pyšek, P.; Jarošík, V.; Hulme, P.E.; Pergl, J.; Hejda, M.; Schaffner, U.; Vilà, M. A global assessment of invasive plant impacts on resident species, communities and ecosystems: The interaction of impact measures, invading species' traits and environment. Glob. Chang. Biol. 2012, 18, 1725-1737. [CrossRef]

6. Vilà, M.; Espinar, J.L.; Hejda, M.; Hulme, P.E.; Jarošík, V.; Maron, J.L.; Pyšek, P. Ecological impacts of invasive alien plants: A meta-analysis of their effects on species, communities and ecosystems. Ecol. Lett. 2011, 14, 702-708. [CrossRef]

7. Ehrenfeld, J.G.; Kourtev, P.; Huang, W. Changes in soil functions following invasions of exotic understory plants in deciduous forests. Ecol. Appl. 2001, 11, 1287-1300. [CrossRef]

8. Lata, J.C.; Degrange, V.; Raynaud, X.; Maron, P.A.; Lensi, R.; Abbadie, L. Grass populations control nitrificationin savanna soils. Funct. Ecol. 2004, 18, 605-611. [CrossRef]

9. Subbarao, G.V.; Rondon, M.; Ito, O.; Ishikawa, T.; Rao, I.M.; Nakahara, K.; Lascano, C.; Berry, W.L. Biological nitrificationinhibition (BNI)-Is it a widespread phenomenon? Plant Soil 2007, 294, 5-18. [CrossRef]

10. Dassonville, N.; Guillaumaud, N.; Piola, F.; Meerts, P.; Poly, F. Niche construction by the invasive Asian knotweeds (species complex Fallopia): Impact on activity, abundance and community structure of denitrifiers and nitrifiers. Biol. Invasions 2011, 13, 1115-1133. [CrossRef]

11. Bardon, C.; Piola, F.; Bellvert, F.; Haichar, F.Z.; Comte, G.; Meiffren, G.; Pommier, T.; Puijalon, S.; Tsafack, N.; Poly, F. Evidence for biological denitrification inhibition (BDI) by plant secondary metabolites. New Phytol. 2014, 204, 620-630. [CrossRef] [PubMed] 
12. Hortal, S.; Lozano, Y.M.; Bastida, F.; Armas, C.; Moreno, J.L.; Garcia, C.; Pugnaire, F.I. Plant-plant competition outcomes are modulated by plant effects on the soil bacterial community. Sci. Rep. 2017, 7. [CrossRef] [PubMed]

13. Castro-Díez, P.; Godoy, O.; Alonso, A.; Gallardo, A.; Saldaña, A. What explains variation in the impacts of exotic plant invasions on the nitrogen cycle? A meta-analysis. Ecol. Lett. 2014, 17, 1-12. [CrossRef] [PubMed]

14. Gallien, L.; Carboni, M. The community ecology of invasive species: Where are we and what's next? Ecography 2017, 40, 335-352. [CrossRef]

15. MacDougall, A.S.; Gilbert, B.; Levine, J.M. Plant invasions and the niche. J. Ecol. 2009, 97, 609-615. [CrossRef]

16. Skurski, T.C.; Rew, L.J.; Maxwell, B.D. Mechanisms underlying nonindigenous plant impacts: a review of recent experimental research. Invasive Plant Sci. Manag. 2014, 7, 432-444. [CrossRef]

17. Bailey, J.P.; Bímová, K.; Mandák, B. Asexual spread versus sexual reproduction and evolution in Japanese Knotweed s.l. Sets the stage for the "Battle of the Clones". Biol. Invasions 2009, 11, 1189-1203. [CrossRef]

18. Parepa, M.; Fischer, M.; Krebs, C.; Bossdorf, O. Hybridization increases invasive knotweed success. Evol. Appl. 2014, 7, 413-420. [CrossRef]

19. Nentwig, W.; Bacher, S.; Kumschick, S.; Pyšek, P.; Vilà, M. More than "100 worst" alien species in Europe. Biol. Invasions 2018, 20,1611-1621. [CrossRef]

20. Lavoie, C. The impact of invasive knotweed species (Reynoutria spp.) on the environment: Review and research perspectives. Biol. Invasions 2017, 19, 2319-2337. [CrossRef]

21. Stefanowicz, A.M.; Majewska, M.L.; Stanek, M.; Nobis, M.; Zubek, S. Differential influence of four invasive plant species on soil physicochemical properties in a pot experiment. J. Soils Sediments 2018, 18, 1409-1423. [CrossRef]

22. Legay, N.; Baxendale, C.; Grigulis, K.; Krainer, U.; Schloter, M.; Bardgett, R.D.; Arnoldi, C.; Bahn, M.; Dumont, M.; Poly, F.; et al. Contribution of above-and below-ground plant traits to the structure and func-tion of grassland soil microbial communities. Ann. Bot. 2014, 114, 1011-1021. [CrossRef] [PubMed]

23. Moreau, D.; Pivato, B.; Bru, D.; Busset, H.; Deau, F.; Faivre, C.; Matejicek, A.; Strbik, F.; Philippot, L.; Mougel, C. Plant traits related to nitrogen uptake influence plant-microbe competition. Ecology 2015, 96, 2300-2310. [CrossRef]

24. Thion, C.E.; Poirel, J.D.; Cornulier, T.; De Vries, F.T.; Bardgett, R.D.; Prosser, J.I. Plant nitrogen-use strategy as a driver of rhizosphere archaeal and bacterial ammonia oxidizer abundance. FEMS Microbiol. Ecol. 2016, 92, fiw09. [CrossRef] [PubMed]

25. Czarnes, S.; Dexter, A.R.; Bartoli, F. Wetting and drying cycles in the maize rhizosphere under controlled conditions. Mechanics of the root-adhering soil. Plant Soil 2000, 221, 253-271. [CrossRef]

26. Warembourg, F.R. $\mathrm{N}_{2}$ fixation in soil and plant systems. In Nitrogen Isotope Techniques; Knowles, R., Blackburn, T.H., Eds.; Academic Press: San Diego, CA, USA, 1993.

27. Díaz, S.; Cabido, M. Plant functional types and ecosystem function in relation to global change. J. Veg. Sci. 1997, 8, 463-474. [CrossRef]

28. Cantarel, A.A.M.; Dumont, M.; Lainé, P.; Lemauviel-Lavenant, S.; Personeni, E.; Pommier, T.; Kastl, E.M.; Diquelou, S.; Desclos-Theveniau, M.; Grassein, F.; et al. Using plant functional traits to explain plant-microorganisms relationships for N-resources acquisition. Ecology 2015, 96, 788-799. [CrossRef]

29. Patra, A.K.; Abbadie, L.; Clays-Josserand, A.; Degrange, V.; Grayston, S.J.; Loiseau, P.; Louault, F.; Mahmood, S.; Nazaret, S.; Philippot, L.; et al. Effect of grazing on microbial functional groups involved in soil $\mathrm{N}$ dynamics. Ecol. Monogr. 2005, 75, 65-80. [CrossRef]

30. Simonin, M.; Richaume, A.; Guyonnet, J.P.; Dubost, A.; Martins, J.M.F.; Pommier, T. Titanium dioxide nanoparticles strongly impact soil microbial function by affecting archaeal nitrifiers. Sci. Rep. 2016, 6, 33643. [CrossRef]

31. Baudoin, E.; Philippot, L.; Chèneby, D.; Chapuis-Lardy, L.; Fromin, N.; Bru, D.; Rabary, B.; Brauman, A. Direct seeding mulch-based cropping increases both the activity and abundance of denitrifier communities in a tropical soil. Soil Biol. Biochem. 2009, 41, 1703-1709. [CrossRef]

32. Parepa, M.; Kahmen, A.; Werner, R.A.; Fischer, M.; Bossdorf, O. Invasive knotweed has greater nitrogen-use efficiency than native plants: Evidence from a 15N pulse-chasing experiment. Oecologia 2019, 191, 389-396. [CrossRef] [PubMed] 
33. Bottollier-Curtet, M.; Planty-Tabacchi, A.M.; Tabacchi, E. Competition between young exotic invasive and native dominant plant species: Implications for invasions within riparian areas. J. Veg. Sci. 2013, 24, 1033-1042. [CrossRef]

34. Grime, J.P.; Hodgson, J.G.; Hunt, R. Comparative Plant Ecology. A Functional Approach to Common British Species; Springe: Dordrecht, The Netherlands, 1989; p. 742. [CrossRef]

35. Bímová, K.; Mandák, B.; Kasparová, I. How does Reynoutria invasion fit the various theories of invasibility? J. Veg. Sci. 2004, 15, 495-504. [CrossRef]

36. Chmura, D.; Tokarska-Guzik, B.; Nowak, T.; Woźniak, G.; Bzdęga, K.; Koszela, K.; Gancarek, M. The influence of invasive Fallopia taxa on resident plant species in two river valleys (southern Poland). Acta Soc. Bot. Pol. 2015, 84, 23-33. [CrossRef]

37. Rosnitschek-Schimmel, I. Effect of ammonium and nitrate supply on dry matter production and nitrogen distribution in Urtica dioica. Z. Pflanzenphysiol. 1982, 108, 329-341. [CrossRef]

38. Chmura, D.; Krywult, M.; Kozak, J.L. Nitrate reductase activity (NRA) in the invasive alien Fallopia japonica: Seasonal variation, differences among habitats types, and comparison with native species. Acta Soc. Bot. Pol. 2016, 85, 3514. [CrossRef]

39. Siemens, T.J.; Blossey, B. An evaluation of mechanisms preventing growth and survival of two native species in invasive bohemian knotweed (Fallopia x bohemica, Polygonaceae). Am. J. Bot. 2007, 94, 776-783. [CrossRef]

40. Barney, J.N.; Tharayil, N.; DiTommaso, A.; Bhowmik, P.C. The biology of invasive alien plants in Canada. 5. Polygonum cuspidatum Sieb. \& Zucc. [= Fallopia japonica (Houtt.) Ronse Decr.]. Can. J. Plant Sci. 2006, 86, 887-905.

41. Hirose, T.; Tateno, M. Soil nitrogen patterns induced by colonization of Polygonum cuspidatum on Mt. Fuji. Oecologia 1984, 61, 218-223. [CrossRef]

42. Tateno, M.; Hirose, T. Nitrification and nitrogen accumulation in the early stages of primary succession on Mt. Fuji. Ecol. Res. 1987, 2, 113-120. [CrossRef]

43. Chen, X.P.; Zhu, Y.G.; Xia, Y.; Shen, J.P.; He, J.Z. Ammonia-oxidizing archaea: Important players in paddy rhizosphere soil? Environ. Microbiol. 2008, 10, 1978-1987. [CrossRef] [PubMed]

44. Könneke, M.; Schubert, D.M.; Brown, P.C.; Hügler, M.; Standfest, S.; Schwander, T.; von Borzyskowski, L.S.; Erb, T.J.; Stahl, D.A.; Berg, I.A. Ammonia-oxidizing archaea use the most energy-efficient aerobic pathway for CO2 fixation. Proc. Natl. Acad. Sci. USA 2014, 111, 8239-8244. [CrossRef]

45. Hou, S.P.; Ai, C.; Zhou, W.; Liang, G.Q.; He, P. Structure and assembly cues for rhizospheric nirK- and nirS-type denitrifier communities in long-term fertilized soils. Soil Biol. Biochem. 2018, 119, 32-40. [CrossRef]

46. Bardon, C.; Piola, F.; Haichar, F.Z.; Meiffren, G.; Comte, G.; Missery, B.; Balby, M.; Poly, F. Identification of B-type procyanidins in Fallopia spp. involved in biological denitrification inhibition (BDI). Environ. Microbiol. 2016, 18, 644-655. [CrossRef] [PubMed]

47. Bardon, C.; Poly, F.; Haichar, F.Z.; Le Roux, X.; Simon, L.; Meiffren, G.; Comte, G.; Rouifed, S.; Piola, F. Biological denitrification inhibition (BDI) with procyanidins induces modification of root traits, growth and N status in Fallopia x bohemica. Soil Biol. Biochem. 2017, 107, 41-49. [CrossRef]

48. Rue, E.A.; Rush, M.D.; van Breemen, R.B. Procyanidins: A comprehensive review encompassing structure elucidation via mass spectrometry. Phytochem. Rev. 2018, 17, 1-16. [CrossRef]

49. Bardon, C.; Misery, B.; Piola, F.; Poly, F.; Le Roux, X. Control of soil N cycle processes by Pteridium aquilinum and Erica cinerea in heathlands along a $\mathrm{pH}$ gradient. Ecosphere 2018, 9, 1-14. [CrossRef]

50. Carey, C.J.; Beman, J.M.; Eviner, V.T.; Malmstrom, C.M.; Hart, S.C. Soil microbial community structure is unaltered by plant invasion, vegetation clipping, and nitrogen fertilization in experimental semi-arid grasslands. Front. Microbiol. 2015, 6, 466. [CrossRef]

(C) 2020 by the authors. Licensee MDPI, Basel, Switzerland. This article is an open access article distributed under the terms and conditions of the Creative Commons Attribution (CC BY) license (http://creativecommons.org/licenses/by/4.0/). 